\title{
The Effects of Globalization on African Culture: The Nigerian Perspective
}

\author{
${ }^{1}$ Dr. Ogechukwu C. Ugbam, ${ }^{2}$ Dr. Benjamin Chukwu, ${ }^{3}$ Dr. Ann Ogbo \\ ${ }^{1,2,3}$ Department of management University of Nigeria Enugu campus
}

\begin{abstract}
The effects of globalization on various aspects of the life of developing nations has always been controversial. Of recent, emphasis has been on the impact of globalization on African culture. There is the fear that ultimately, globalization aims at cultural homogenization and moreover, that the culture that will emerge at the end of the day will be predominantly American, thus Americanization. It is against this background that this paper sets out to assess the effects of globalization on Nigerian culture. This work pursues three specific objectives namely to determine the effects of globalization on Nigerian culture, to ascertain if cultural homogenization is an American agendum, to determine the global implications of cultural homogenization and to ascertain if Nigeria is at the mercy of the forces of globalization culture-wise. Adopting theoretical and judgemental analysis, this work took the following positions with regards to the objectives: Globalization, as a double-edged sword, has impacted both positively and negatively on the Nigerian cultures to the extent that one cannot convincingly prove that its net effect is negative and to state also that the negative effects came as result of Nigerians copying what was wrong in foreign cultures of their own freewill. Therefore, Nigerians should take much of the blame for the extinction and dilution of our culture; There is not enough evidence to show that America is deliberately trying to impose its culture on the rest of the world, if cultural homogenization occurs as a result of acculturation, in this case, a process of natural selection that selects the best part of each culture and combines or unites them to achieve a perfect dominant global culture, humanity will be the better for it. However, a dominant global culture that emerges as a result of the forceful projection and imposition of one culture on the rest of the world is totally undesirable and unacceptable and Culture is perhaps the aspect of globalization for which Nigerians have the power to resist or moderate the process of globalization because we as intelligent human beings have the capacity to discern right and wrong and unless we accept a foreign culture, no force can impose it on us. This work also makes the following recommendations: The first step in preserving our culture is to transcend the inferiority complex that makes us believe that what is foreign is automatically better and realize that culture-wise, Nigeria has a lot that is superior and therefore admired by other peoples, our target should not be to retain our cultures in their pristine order because that is against the law of nature but to direct the process of cultural evolution in such a way that it is positive and in view of the critical role that culture plays in national development, our leaders should be conscious of the fact that there is a global culture competition going on and that if ignored or neglected, it may prove to be insidious and disastrous to a quest for national development.
\end{abstract}

Keywords: Globalization, Culture, Extinction, Africa, Foreign

\section{Introduction}

Although the word globalization was not coined until the second half of the twentieth century, the origin of globalization has been traced back to the period between 1450-1500 AD. A period referred to as the mercantilist period and characterized by the development of trade in the quest for commercial empires to broaden their markets (Amiuwu, 2004:18, Scholte, 2002:4). Since then, propelled by incredible advancements in transportation and information technology, globalization has practically shrank the world to one global village. Initially, globalization was seen as an economic phenomenon and in fact, some economists still define it from a purely economic perspective. However, it is now obvious that although it was triggered by economic motives, it has far reaching effects in all aspects of life especially in the areas of politics, culture, technology and the environment.

Africans have always been sceptical of the benefits of globalization generally and most commentators on globalization of African extract argue that the continent has not benefited from the process of globalization and that it has actually exacerbated the problem of poverty in the continent. In fact, some of them blame globalization for practically all that is wrong in Africa (Adei, 2004:6-7. Amiuwu, 2004:22, Aluko et al, 2004:119-130). Of recent, emphasis has been on the impact of globalization on African culture. Afisi (2008:1) observes that the implications of globalization is that the world is turning into the practice of one market economy, one liberal democracy and ultimately one westernized cultural heritage and Nicolaides (2012:118) warns that African culture is being diluted, to the extent that it is atrophying. The concern over the cultural implications of globalization is for good reasons; apart from the fact that culture has serious business 
implications, it is the people's identity and also, a binding force that holds them together. Consequently, to lose one's culture tantamounts losing one's identity and as stated by Awoniyi (1978), "a society cut off from its roots may thrive for a while on its own momentum but eventually it will wither like cut flowers in a vase."

At the core of the concern over the implications of globalization are the concepts of homogenization and Americanization. It is believed that the aim of globalization is the emergence of one global culture and that the culture that will ultimately emerge as the global culture will be predominantly American (Nicolaides 2012:123). The tone of the discussions on Americanization of global culture suggests that there is a deliberate and concerted effort by America to impose its culture on the rest of the world.

It is against this backdrop that this work was conceived with the major aim of critically examining the impact of globalization on African culture using Nigeria as a case study. Specifically, this work will seek for answers to the following questions:

1. What have been the effects of globalization on Nigerian culture?

2. Is cultural homogenization an American agendum?

3. What is the global implication of cultural homogenization?

4. Culture-wise, is Nigeria at the mercy of forces of globalization?

\subsection{Globalization}

\section{The Concepts Of Globalization And Culture}

Giddens (1996) once stated that there are few terms that we use so frequently but which are in fact as poorly conceptualized as globalization. Probably in support of this observation, Scholte (2002:3) opines that every study of globalization should include a careful and critical definition of the word itself. He believes that a "muddled or misguided core concept compromises overall comprehension of a problem while a sharp and revealing definition promotes insightful, interesting and empowering knowledge, and also an understanding that helps us to shape our destiny in positive direction". He studied most of the existing definitions of globalisation and came to the conclusion that they are parochial and deficient because they define globalisation as being the same as internationalization, liberalization, universalization, or westernisation. Globalization contains elements of the four concepts mentioned above but cannot rightly be defined exclusively in terms of any of them. Definitions abound in the literature of globalisation and they vary depending on who is defining and the perspective from which the person is defining. According to Amiuwu (2004), definitions of globalisation could be institutional/organisational; process, system or value driven, ideological or a combination of some or all of the above.

Having reviewed a considerable number of definitions of the topic, it is the position of this paper that the two definitions below are the most suitable for the purpose of this paper. The first is that proffered by the bank of industry which sees globalisation as the closer integration of countries and peoples of the world and the breaking down of artificial barriers to the flow of goods, services, capital, knowledge and people across national borders; a process of creating a global market of investments, trade and information through the integration of economic decision making on consumption, investment and savings across the world (Bank of Industry 2004:1) and the second one by Onyeonoru (2003:37) which sees globalisation as the intensification of world-wide social relations which link distant localities in such a way that local happenings are shaped by events occurring many miles away and vice-versa. According to Abubakar (2003:15-19), universality is a major feature of globalisation and an issue, object, value, institution or practice is globalized if either through commerce, production, consumption, politics and information technology it is visible or considered relevant in global centres. In other words, globalisation entails universalization whereby the objective, practices or even values transcend geopolitical boundaries, penetrating the hitherto sovereign nation state and impacting the orientation and value system of the people.

According to Scholte (2002: 4), the term "globalization was not coined until the second half of the twentieth century". Amiuwu (2004: 18-28) believes that the term was first coined in the 1980s. Some scholars however believe that the origin of globalisation dates back to the period between 1450-1500AD which was characterized by the development of trade in the quest for commercial empires to broaden their markets. This period is usually referred to as the mercantilist period (Adejo 2003:1-10). Amiwu (2004:19) observes that the transatlantic slave trade presents the saddest image of globalisation through the ages and that the current form of manifestation of globalisation is as a result of the determination by western countries to strengthen relations for stability and mutual benefits after the Second World War. In fact most literature on globalisation link it to ancient forms of international trade. Onyeonoru (2003:36) for instance believes that it began "through an endless series of economic transactions which linked Europe, Asia, Africa and the America." He is also of the opinion that the current form of globalisation does not show any clear break from the past. The post 1970s constituted the current phase of globalisation that has witnessed the collapse of welfarism and socialism to a great extent. This phase has also witnessed the birth of international global organisations and institutions. Such 
organisations include the international monetary fund (IMF), the World Bank, the Group of Seven Industrial Nations (G7), General Agreement on Trade and Tariff (GATT), European Economic Community (ECC), European Union (EU), and the World Trade Organisation (WTO) (Nwana 2004:1). Sawyer (1998: 17) sees the current wave of globalisation as desperate attempt by "international capitalism to recover lost grounds due to ideological shifts towards alternative paradigms which African countries adopted since independence....... especially with the collapse of the Soviet Union and the unchallenged hegemony of capitalism and neo-liberal ideology".

The key elements of the process of globalisation are the interconnection of sovereign nations through trade and capital flows, harmonization of economic rules that govern relationships between sovereign nations, creating structures to support and facilitate dependence and interconnection, and creation of a global market place (Bank of Industry 2004:1). Generally, the factors that helped to shape and facilitate globalisation according to Scholte (2000) are as follows:

1. The emergence of global consciousness.

2. Development in capitalism with regards to the organisation of production, marketing, accumulation and transfer of capital.

3. Trans-national production, large movement of financial assets across borders, concentration of capital in few countries and internationalisation of production by companies, marketing and consumption.

4. An enabling regulatory framework especially through supranational institutions like WTO, IMF, World Bank, and GATT.

Fischer (2001), the first deputy managing director of the International Monetary Fund (IMF), described globalisation as being multi-faceted with economic and social, political and environmental, and cultural and religious dimensions that affect everybody in some way. Specifically, he sees its implications to "range from the trade and the investment flows that interest economists, to changes that we see in our everyday lives; the ease with which we can talk to people all over the world; the speed and ease with which data can be transmitted around the world; the ease of travel; the ease with which we can see and hear news and cultural events around the world, and most extraordinarily, the internet, which gives us the ability to access the stores of knowledge in virtually all the worlds computers."

Globalisation is a highly controversial topic especially in terms of whether it is a good thing and should be allowed to continue, the appropriate form it should take and how it impacts nations and peoples. The way people see globalisation will definitely differ depending on how it impacts their lives and this in turn depends on the part of the world they belong to. For instance, the way it impacts people in the underdeveloped countries will be entirely different from the way it impacts people in the developing and developed countries. The spread of divergent views on the topic is reflected in the views of the three prominent schools of thought on the issue - the neo-liberals, the Keynesians, and the radicals. The neo-liberals, followers of John Locke and Adam Smith, believe in the market forces, competition and removal of all barriers. They advocate the deepening of globalisation through the dismantling of official regulations because they believe that a more globalised economy will be more efficient because the removal of market constraints and other rigidities lead to growth, increase in trade, efficiency.

\subsection{Culture}

Culture has been defined as the programming of the mind which distinguishes the members of one human group from another..... the interactive aggregate of common characteristics that influence a human groups response to its environment (Adler 1983 ); the way of life of the members of a society, the collection of ideas and habits which they learn, share and transmit from generation to generation (Edewor 2003:195); that complex whole which includes knowledge, belief, art, morals, law, custom and any other capabilities and habits acquired by man as a member of society; and the set of tangible and intangible elements-things like diet, tools, technology, language and values-that gives shape and meaning to everyday lives of a particular group of people (Kanagy and Kraybill 1999). The concept of culture consists of the values the members of a given group hold, the norms they follow, and the material goods they create. It refers to the way of life of the individual member of groups within a society; how they dress, their religious ceremonies and leisure pursuit (Oni 2005:9-7). From the definitions above it is clear that culture is a very broad concept that generally encompasses basically every aspect of human life.

People consider culture to be important for several reasons. Firstly, it is seen as defining peoples' identity and consequently, it has been argued that a people without culture is a people without identity. By defining peoples' identity, culture helps to distinguish between or among peoples of different societies of communities. Summing it up, Adedimeji (2006:10) declares that "to be removed from one's culture is to be deprived of one's identity. To lose one's identity is to be tossed in the wind fluterring along like a leaf separated from its tree." Secondly, culture is considered to be very important in ensuring the survival and development of a community. In support of this, Adedimeji (2006:10) opines that a society robbed of its culture can only 
marginally survive.......anyone that loses his cultural or linguistic legacy is bound to expire. Thirdly, culture plays a critical role in ensuring continuity in any given society by helping to transmit values, beliefs, rituals, etc from one generation to the other. Since culture usually evolves as human beings attempt to meet the challenges of living in their environment (Nwaegbu, Eze and Asogwa, 2011), it obviously plays a key role in facilitating human adaptation which in turn is necessary for long term survival. Finally, culture features in both the internal and external environment of business and influences purchasing decisions. It is therefore, a relevant variable in economic development.

One important fact to bear in mind about the nature of culture is that it is dynamic and therefore is subject to change. Since culture evolves as a result of the efforts of human beings to adapt to their environment, it is to be expected that as the environment changes, culture will also change. Nwaegbu et al (2011) state that the process of expanding culture has been under way for many for many centuries. Expansion in this case connotes change. Moreover, culture is a human thing and as the human spirits become more evolved, their perception of their environment and of right and wrong changes and these ultimately reflect in the changes in their culture. An aspect of the nature of culture that is hotly debated is that of the equality or otherwise of culture. There is a school of thought that believes that although cultures differ, they should all be considered to be equal. In other words, no culture can be considered to be superior to another (Sotshanagane, 2002, Holzapfel 1997:13 and Taylor (1994). Furthermore, they argue that right and wrong are relative concepts and that what an individual may consider to be right based on his culture may be considered to be wrong when viewed from the perspective of a different culture. Elaborating this position, Sotshanagane (2002:212) states that "when you say that abortion or euthanasia is wrong, this just means that your society disapproves of them. For other societies, based on their belief, abortion may be alright." Suffice it to say that the fact that different societies have different perceptions of right and wrong does not in any way imply that they are relative. They are constant; absolute, if you like. The variance in their perception among different peoples is accounted for by the differences in the level of spiritual development of the people involved. Even at that, there is hardly any culture in which lying, cold blooded murder and rape are considered to be right. When two cultures are compared, none may be considered to be totally superior in all aspects, one will definitely be superior in some aspects.

\section{The impact of globalization on Nigerian culture}

(Norberg-Hodge 2006) have observed that "perspectives on globalization have mainly tilted from its advocates to its opponents. While supporters of globalization see it as a welcome and veritable phenomenon bringing about improved trade, networking and collaboration among peoples regardless of their geographical locations, opponents of globalization see it as a new form of colonialism that further enriches the rich and the powerful.............." Nigerians belong to the latter category. Most Nigerians believe that the process of globalization has impacted negatively on their countries development and that the country would have been better off without it. They blame globalization for all that is wrong with the country. For instance,

Aimiuwu (2004:22), states as follows:

Regarding the poor countries, globalisation is accused of entrenching poverty, and ruthlessly grinding the poor everywhere, not only widening that gap between the rich and the poor, between countries and within countries, but actually, like Dracular, thriving on the blood of the poor. While foreign direct investment from rich countries go to other rich countries, only dumping appear in the receipt book of poor countries.

Aluko et al (2004:119-130) see globalization as the renewed attempt to consolidate the re-colonisation process and observes that

Every element of the current crisis of collapse of industries, collapse of educational and health facilities, collapse of infrastructure (power, transportation, water supply and communication), degradation of the environment, inflation, escalating debt bill, weakening of the currency, ethnic and religious violence and collapse of public security is traceable to the renewed attempt to consolidate the re-colonization process.

Afisi (2008:1) opines that the continent of Africa (to which Nigeria belong) is still ravaged with poverty, unemployment, ethnic and religious crisis, inter-tribal wars and under-development which globalization is intended to eradicate and that globalization appears to threaten the economic, socio-cultural, linguistic, educational and political independence of all people in the world such that the question that befuddles every nation is "how can I survive?"

This sentiment prevails when globalization is viewed from the cultural perspective. Major critics of globalization from Africa have argued that globalization is destructive to African culture and development (Oni 2005:9). Because of the close integration and interaction of different peoples which it engenders, globalization exerts more cultural pressure than people imagine. Waters (1995:3) sees globalization as the direct consequence of the expansion of European culture across the planet via settlement, colonization and cultural mimesis while Afisi (2008) sees it as purely an attempt to spread western culture with its attendant capitalist, socio-economic and political nuances. From a cultural perspective, most Africans see globalization as merely another form of imperialism or colonialism. According to Wilfred (1997:42-43), "present day globalization is but a continuation 
of a long tradition of over five hundred years, the tradition of imperialism. Globalization is only the latest phase and expression of this uninterrupted history of domination and subjugation of peoples, nations and conquistadors and colonizers. It is a tradition of political, economic and cultural domination of some nations over others."

In examining the impact of globalization on Nigerian culture, it is important to realize that strictly there may be a more appropriate term. Prior to the end of the $19^{\text {th }}$ century, the name Nigeria did not exist and the geographical region now referred to as Nigeria was inhabited by disparate ethno-linguistic groups such as the Oyo Empire, Kanem-Borno Empire, Benin Kingdom and Sokoto Caliphate. During the colonial era, Britain forcefully welded them together as one country for administrative convenience (Adedimeji, 2006). Although the disparate groups co-existed peacefully, there was no evidence that they actually wanted to unite into one entity. Centuries after they were brought together as one, a national culture is yet to emerge because each of the numerous ethnic groups has jealously guarded their cultures. This is why English language is still the country's lingua-franca.

From an empirical point of view, there have undoubtedly been clearly observable changes in Nigerian cultures over the decades. The negative aspects of these changes have been aptly captured by various commentators on the issue. Ogunjimi and $\mathrm{Na}$ 'Allah (2005:36) opine that

The peculiar Nigerian cultural values, like languages, are being eroded by the pop culture brought about by globalization. Greeting norms, cuisine, appearess (that is, appearance and dress), custom, occupations, religion and cultural components are giving way to acculturation "the suppression and subjugation of African culture," a tragic phenomenon that is fast destroying the original cultural complexion of not only the budding generation but even the adults.

Odimegwu, (2007:357) observes that

At the various levels of education particularly the secondary and tertiary institutions; teachers and pupils, lecturers and students engage in various forms of corrupt practices which negate the communal spirit and are detrimental to the goals which education ought to achieve. Such evils as admission racketeering, exam malpractice, sexual harassment of students by lecturers and vice-versa, sale of marks, lack of sense of duty, indifference to social responsibility and public property, indecent dressing and the general decay of the moral sense, all culminating in abysmally low performance of students are now common features of most secondary and tertiary educational institutions.

He blames all this on the individualistic trend which has permeated all levels of the educational system. All the ills he observed exist in Nigerian educational institutions, but it will be wrong to blame it on individualism. The education system we operate is borrowed from the West from where individualism also creeped into our culture. But these ills are not found in any significant level in their educational system. So there must be something other individualism responsible for these negative tendencies in Nigerian education system.

Oni (2005) sees Nigerian cultures as being weak when compared with western culture and consequently, bound to lose in a battle against western culture. He laments that

"the situation in Africa today is so pathetic as a result of the gradual admittance of western culture at the detriment of our own culture. Africa has consequently changed from a land of culture, nature; of tradition and rural setting where the cockcrow signals the dawn of a new day. The worship and belief of gods and goddesses has been washed away by belief and worship of the one God"

Are we to go back to the worship of gods and goddesses long after the world has recognized the existence of one supreme-being just so that we will be seen as maintaining our culture? In fact, Oni in the rest of this work blamed globalization for all that is presently wrong with our way of life in Nigeria.

The negative effects of globalization seem to be more conspicuous and alarming among our youths. Oni (2005:2) observes that Nigerian youths are rapidly losing touch with cultural values and that this could be seen in the alien culture which they portray; their bizarre dressing, dancing and language and so on which invariably affect other aspects of social life. Unfortunately, this is not peculiar to Nigerian youths. Nicolaides (2012:123) made a similar observation about South African youths. He states as follows:

The younger generation of teenagers in south Africa have for the most part abandoned their African culture and language, and often religion and try to be hip by imitating their mainly American rap artist role models who for most part display an acute lack of values and act immorally on television shows and who promote promiscuous behaviour especially in the lyrics of the music they write.

Youths are supposed to promote our culture and at the same time help to transmit it from one generation to the other. Therefore, it is deplorable when they fail to play this role. As Bello and Adesemoye (2012):

"..........teenagers and youths generally are vital segments of the society who could be instrumental in promoting African cultures. But unfortunately, the mentality and lifestyle of the teenagers in African societies have been grossly affected by exposure to western films to some extent that rather than promoting African cultures, they have become hardened acolytes and promoters of western culture." 
Akande (2002) blames globalization for the extinction of 22,000 indigenous cultures in the last decade and projects that approximately 90 per cent of the world's languages will disappear in the next century as a result of globalization. One can go on and on and on in documenting all the negative effects of globalization on Nigerian cultures as documented by opponents of globalization. However a balanced and unprejudiced presentation will require that we also acknowledge the positive impacts of globalization on our ways of life (of which there are many) and also critically examine the situation to see the extent to which globalization is actually responsible for these negativities. The starting point will be to ask the question: assuming there is no such thing as globalization, will Nigerian cultures be in their pristine forms? The answer is no! Culture, like most other things in life, driven by the law of constant development, is never static but evolves over time. The trajectory of this evolution is influenced by among other things, the changes in the immediate environment in which a given group of people exist, changes in the spirituality of the people involved which could be positive or negative which affects their perception of right and wrong, and contact with other cultures. So, without globalization, Nigerian cultures will still have changed; most of the changes we are blaming globalization for would still have occurred. It is important to realize that some of the things that are considered to be among the negative effects of globalization on culture are not necessarily bad even though they are alien to Nigeria - eating with cutlery from plates and spoons instead of bare hands and from calabash, sitting on chairs instead of the floor, belief in one supreme God instead of gods and goddesses. It is also equally important to realize that globalization may not necessarily be responsible for some of the bad aspects of our culture that it is being blamed for - crime, corruption, and sexual promiscuity. All these were present in our society before the advent of the white man. In fact, it is difficult to determine the extent to which globalization should be blamed for indecent dressing prevalent in our society today. If the portrayal of the dressing code of our ancestors by our movie industry (Nollywood) is anything to go by, then one can safely state that our female folks have always had a penchant for wearing clothes that reveal parts of their body.

Finally, let us acknowledge the fact that through the process of acculturation, African cultures generally and Nigerian cultures in particular have been refined as a result of contact with the western world. There was a time in Nigeria when twins were considered a taboo and were killed, people that were afflicted by sicknesses that could not be diagnosed were taken to evil forests and left to die unattended because it was believed that they were experiencing the wrath of the gods, sickle-cellers were subjected to all sorts of embarrassing and inhuman treatments because they were adjudged to be possessed by evil spirits (Ogbanje) who use them to torment their parents, people were buried alive with kings under the erroneous impression that they will continue to serve the kings even in the beyond. All these stopped when the missionaries came to our country. In support of the ongoing argument, Nicolaides (2012:123) acknowledges the fact that in some cases, ethically sound values on issues such as human rights and democracy are spread through Americanization. Beyond these issues, Nigeria has benefited tremendously from globalization in other spheres of life. Our culture as far as mass communication is concerned was to use town-criers who are equipped with nothing but their voices and a gong. The demerits and limitations of this mode of communication are obvious especially when compared with we can achieve with the internet or a digital phone today.

In conclusion one can state that globalization, as a double-edged sword, has impacted both positively and negatively on the Nigerian cultures to the extent that one cannot convincingly prove that its net effect is negative and to state also that the negative effects came as result of Nigerians copying what was wrong in foreign cultures of their own freewill. Therefore, Nigerians should take much of the blame for the extinction and dilution of our culture.

\subsection{Cultural Homogenization: An American Agendum?}

The tone of the discourse on the effects of globalization on culture suggests a belief and fear that globalization is tending towards a homogenization of global culture. That is, a situation where all the peoples have just one culture. Coupled with this is the fear that this one culture that will emerge will ultimately be the American culture, thus Americanization. Bello (2010) opines that homogenization of cultural relations worldwide has been a key factor in the process of globalizing while Nicolaides (2012:118-123) states that American norms, values and practices are being conveyed across the Atlantic as the suitable mode of behaviour for Africans. As a consequence of this cultural migration, Africa's rich culture is being degraded, and is viewed as inferior by others and that globalization is in practice homogenizing popular culture by inculcating an ethos of a western, mainly American cultural industry, which also has roots in Britain and western Europe. Elaigwu (1997) observes that from coca-colanization of the world, we have arrived at CNNization of the world. Some people see it differently. Sotshanagane (2002:223) is of the opinion that contrary to the popular belief that globalization is tending towards homogenization of world culture, that it actually makes for multi-culturalism stating as follows: 
"Indeed in some respects, globalization fosters and allows for differences. A trivial example is that almost every town of any size in the world offers residents the choice of food such as French, Italian, Thai, Indian, Mexican, Chinese, Arabic, etc. We have multiculturalism not only in cuisine but areas of media, education, finance, computer, manufacturing, corporate management, and in religion." informs us that

In support of this, Michael Lynton (2007), a key player in the American movie industry (Hollywood)

Those who oppose globalization are especially sensitive about loss of culture. But the American film industry does not contribute to the homogenization or Americanization of culture............ instead of creating a single boring global village, the forces of globalization are actually encouraging the proliferation of cultural diversity. More than half of Hollywood films come from France, Germany, India Japan and US producers quickly recognize and respect talent from many diverse points on the globe.......major studios also encourage and create films for diverse markets- China, Mexico, Russia, and other nations. Original television series emerge from many markets and selecting the most popular, producers transform shows for other markets using local talents and cultural nuances.

Homogenization or Americanization of global culture is discussed as if there is really a concerted effort and well articulated grand strategy by America to impose its culture on the rest of the world. Is this a fact? If the following facts documented by Adedimeji (2006) are true, it becomes doubtful if actually there is a grand design by America to impose her culture on the rest of the world;

1. The dawn of civilization saw the policy shift from "English only" to "English plus" in the US. While English only movement used to be popular campaigning for the use of English alone in private and public life as a way of forging linguistic unity, the English plus movement considers it restrictive and likely to rob America of the values of heritage languages.

2. Approximately 337 languages are spoken or signed by the US population out of which 176 are indigenous to the area.

3. Three states in the US are officially bilingual: Lousiana (English and French), New Mexico (English and Spanish), Hawaii (English and Hawaiian).

4. Three American territories are also bilingual: American Samoa (Samoa and English), Guam (English and Chamorro) and Puerto Rico (Spanish and English)

5. At least one US territory is trilingual: Northern Mariana Islands (English, Chamorro and Carolinian).

6. Despite the prominence of English in the world and its indigenous status in the US (spoken by $82 \%$ of the population), it is not the US official language as the US has none.

7. US government encourages the teaching and learning of several world languages including those of Nigeria in American schools, colleges and universities.

There are two possible explanations for the way it seems that the whole world is wholeheartedly accepting American culture and replacing their indigenous culture with it. Firstly, whenever two cultures come into contact, acculturation takes place naturally and this acculturation process is influenced by a natural law that operates to the effect that what is weak is usually attracted to what is strong. We have already seen that culture is a concept that represents peoples' way of life. The strength of a culture can be measured in terms of the extent to which it embodies positive qualities and values that enhance peoples' standard of living. The implication is that often when people accept western culture, it is because they are actually better than what they posses. Secondly, majority of Africans are plagued by inferiority complex which makes them believe that the western way of life is superior to theirs in all aspects. Consequently, they are eager to accept anything western while shunning anything African. Lamb (1986:140) blames this on the colonialists stating that the cruellest legacy they left on the African continent was a "lingering inferiority complex, a confused sense of identity." In support of this, Maduagwu (1999:4) opines that "ever since their experience with colonization, African countries have been unable to, independently, articulate or chart their own history, culture and identity." If people today are still burdened with inferiority complex implanted in them over five decades ago, we might as well throw in the towel and stop complaining of western dominion because it means that we have completely lost the capacity to reason for ourselves.

The culture that remains in its pristine order till eternity is a myth and one that operates as a closed system will soon die of inbreeding. According to Oni (2005:15), "if we become exclusively African oriented, we may as well never develop or preserve our ancient cultures which need to be improved by the fusion of other cultural, educational and scientific models." It is a law of nature that true perfection can only be achieved through union. No one culture is perfect but each culture has part of what is required to build a perfect culture. If cultural homogenization occurs as a result of acculturation, in this case, a process of natural selection that selects the best part of each culture and combines or unites them to achieve a perfect dominant global culture, humanity will be the better for it. However, a dominant global culture that emerges as a result of the forceful projection and imposition of one culture on the rest of the world is totally undesirable and unacceptable. 
Americans have their own cultural worries because they are concerned over the proliferation of other languages in America due mainly to immigrants into the United States (Nicolaides, 2012:126). Moreover, not all Americans are satisfied with their culture. Sotshanagane (2002:228) reports that

Just about $60 \%$ of Americans, roughly the European share rated it favourably while 39\% rated it unfavourably. Nor are Americans overjoyed to see their popular culture spread around the world. Asked how they feel when they see McDonald opening up in cities around the world or when they hear about the popularity of American TV shows in other countries, only $43 \%$ said they have positive feelings, $43 \%$ said they have mixed feelings and 5\% said they have negative feelings.

\subsection{Nigeria, Culture, and the forces of globalization}

Africa has always been sceptical of the net benefits of globalization. Of late, it seems the continent has adopted a defeatist attitude towards the process of globalization. We complain so much of how much globalization is impoverishing the continent, how it is impacting negatively on our political process and democracy, how it is destroying our physical environment and how it is killing our cultures. We talk about all this as if we are totally at the mercy of the process of globalization. We have been told that America is in a position to reshape norms, alter expectations and create new realities and that America decides what is important across the globe (Lapham, 2001, Nicolaides, 2012). The truth is that with respect to globalization and culture, our faith and our future is in our hands. Culture is perhaps the aspect of globalization for which people have the power to resist or moderate the process of globalization because we as intelligent human beings have the capacity to discern right and wrong. Unless we accept a foreign culture, no force can impose it on us. The starting point is for us to realize that African culture has much that we can be proud of and offer to the rest of the world while at the same time acknowledging that other cultures have features that will help to improve our culture. Our target should be to continually improve our culture and not to maintain it in its pristine state. Nobody can lay claim to globalization- it is complex and vast beyond the control of anybody or nation; the same tools that the western world use to showcase their culture- information and communication technology- is available to anybody who wishes to use it. We should start seeing globalization as more of a challenge than as a problem. Other parts of the world are taking steps to safeguard their culture. Nicolaides (2012) states that in an effort to quell American cultural domination, a number of countries like France and Germany are striving to slow Americanization down by imposing higher taxes and tariffs on all foreign companies and investors. It may not be appropriate for Nigeria to stifle economic activity in order to protect her culture. The point, however, is that other countries are taking measures to protect their culture; Nigeria should follow suit.

\section{Dominant Arguments (Positions), Conclusion and Recommendations}

\subsection{Dominant Arguments (Positions)}

1. Globalization, as a double-edged sword, has impacted both positively and negatively on the Nigerian cultures to the extent that one cannot convincingly prove that its net effect is negative and to state also that the negative effects came as result of Nigerians copying what was wrong in foreign cultures of their own freewill. Therefore, Nigerians should take much of the blame for the extinction and dilution of our culture.

2. There is not enough evidence to show that America is deliberately trying to impose its culture on the rest of the world.

3. If cultural homogenization occurs as a result of acculturation, in this case, a process of natural selection that selects the best part of each culture and combines or unites them to achieve a perfect dominant global culture, humanity will be the better for it. However, a dominant global culture that emerges as a result of the forceful projection and imposition of one culture on the rest of the world is totally undesirable and unacceptable.

4. Culture is perhaps the aspect of globalization for which Nigerians have the power to resist or moderate the process of globalization because we as intelligent human beings have the capacity to discern right and wrong. Unless we accept a foreign culture, no force can impose it on us. The same tools that the western world uses to showcase their culture- information and communication technology- are also available to anybody who wishes to use it.

\subsection{Conclusion}

Having critically examined and analysed existing opinion and empirical evidence with regards to the effect of globalization on Nigerian cultures, this work concludes that although there has been some negative changes in our cultures, globalization has contributed significantly to the upliftment of our cultures and still holds the potential for more positive contributions to our way of life. The negative changes came about as a result of our willingly embracing them and not as a result of a deliberate scheme by the west to impose their culture on ours. Consequently, to manage the effects of globalization on our culture effectively, we should first 
of all realize that there are some aspects of our cultures that are superior to what other foreign cultures has to offer and also, that there are some aspects of foreign cultures that are superior to ours. Based on this, we can positively direct the trajectory of the evolution of our cultures by judiciously choosing what to change and what to preserve. Also, if cultural homogenization occurs as a result of acculturation, in this case, a process of natural selection that selects the best part of each culture and combines or unites them to achieve a perfect dominant global culture, humanity will be the better for it but a dominant global culture that emerges as a result of the forceful projection and imposition of one culture on the rest of the world is totally undesirable and unacceptable.

\subsection{Recommendations}

It seems that Nigerians have on their own, undertaken the responsibility of preserving and projecting what they consider to be good in their culture. The Nigerian entertainment industry, particularly Nollywood, is taking the lead in this case. First of all, it is probably the only industry in Nigeria that is owned exclusively by Nigerians and basically majority of the artists are of Nigerian extract. There theme also is usually Nigerian or indigenous. The fashion industry is also becoming more Nigerian. Our opinion leaders and office holders seem to have realized that Africans are better off in African clothings as they now seem to favour Nigerian caftans in favour of western suits most of the time as opposed to what used to be the case a few years ago. Most fast food outlets that opened about two decades ago when Nigerians embraced meat pies and burgers and the likes ran into difficulties along the line because when the euphoria waned, Nigerians went back to their indigenous dishes. The ones that that survived among this fast food joints were those that adapted by adding indigenous foods to their menu. Nigerian mothers, though few of them, are also making efforts to curb indecent dressing among the ladies. In the light of the above, this work makes the following recommendations:

1. The first step in preserving our culture is to transcend the inferiority complex that makes us believe that what is foreign is automatically better and realize that culture-wise, Nigeria has a lot that is superior and therefore admired by other peoples. In this, the National Orientation Agency (NOA) and the Nigerian movie industry (Nollywood) have a lot to offer.

2. Our target should not be to retain our cultures in their pristine order because that is against the law of nature but to direct the process of cultural evolution in such a way that it is positive. This can be achieved by judiciously selecting what to preserve and what to change.

3. In view of the critical role that culture plays in national development, our leaders should be conscious of the fact that there is a global culture competition going on and that if ignored or neglected, it may prove to be insidious and disastrous to a quest for national development. They should there take time to craft and implement a cohesive and holistic competition grand strategy in this regard.

\section{References}

[1]. Abubakar, D. (2001) "Globalisation, Social Sciences and Nigeria in The 21st Century" Nigeria Social Scientist, Vol. 4., No.1.

[2]. Adedimeji, Mahfouz (2006) Globalization and the Survival of the Nigerian Cultural and Linguistic Heritage: The American Paradigm. Department of English, University of Ilorin, Nigeria.

[3]. Adejo, M. A. (2003) "The Roots of Globalization: A Historical Review" Journal of Globalization and International Studies Vol. 1, No. 1. December.

[4]. Adei, S. (2004) "Impact of Globalization on Management: The African Perspective" Management in Nigeria Vol. 39/40, No.2/1.

[5]. Afisi, Oseni Taiwo (2009) "Globalization and value system" Lumina 22(2).

[6]. Akande, Wole (2002) Drawback of Cultural Globalization. Available @ http://www.org/globali

[7]. Aluko, M. A. O., Akinola, G. O. \& Sola, F. (2004) "Globalisation and the Manufacturing Sector: A Study of Selected Textile Firms in Nigeria" Journal of Social Sciences 9(2).

[8]. Amiuwu, L .E. A. (2004) "Globalisation: The Human Resource Challenge”, Management in Nigeria Vol. 39/40, No.2/1

[9]. Awoniyi, T.A (1978) Yoruba Language in Education: An Historical Survey 1800-1974 in Oni, Adesoji A (2005) Globalization and its Implication on African Culture and Development: Challenges for Education. International Journal of African and African American Studies 4(2).

[10]. Bank of Industry (2004) "Globalization and Industrial Development in Nigeria:

[11]. Which Way Forward" Www.Boi-Nig.Com/Research Term Papers.

[12]. Bello, S (2010) Communication and Cultural Promotion for Sustainable Development: The Challenges of Globalization. In Semiu Musa Bello and Adesemoye (2012) "Western Films and Teenagers in Nigerian Societies: The Question of Cultural Promotion." Continental journal of Arts and Humanities 4(2).

[13]. Edewor, P.A (2003) Basic Concepts in Culture In Adedimeji, Mahfouz (2006) Globalization and the Survival of the Nigerian Cultural and Linguistic Heritage: The American Paradigm. Department of English, University of Ilorin, Nigeria.

[14]. Elaigwu, Isawa J. (1997) "From Might to Money: The Challenging Dimensions of Global Transition to the 21 st Century" (1995 NIPSS Distinguished Annual Lecture). Kuru: National Institute for Policy and Strategic Studies.

[15]. Fischer, S. (2001) "The Challenges of Globalization in Africa" The France-Africa

[16]. Summit, Yaounde Cameroun, 19 January.

[17]. Holzapfel, J (1997) In America In Sotshangane Nkosinathi (2002)" What Impact Globalization has on Cultural Diversity" Alternatives:Turkish journal of international relations. I(4)

[18]. Kanagy, C.L and Kraybill (1999) The Riddles of Human Society In Oni, Adesoji A (2005) Globalization and Its Implication on African Culture and Development: Challenges for Education. International Journal of African and African American Studies 4(2)

[19]. Lamb, D. (1986) The African: Encounters from the Sudan to the Cape. London:Longman Press. 
[20]. Lapham, L.H (2001) “The American Rome: On the Theory of Virtuous Empire,” Harper's Magazine, August.

[21]. Lynton Michael (2007) "Globalization and Cultural Diversity," The wall street journal, 12 September.

[22]. Nicolaides A (2012) "Globalization and Americanization- The Hijacking of Indigenous African culture." Global Advanced Research Journal of History, Political Science and International Relations, 1(6).

[23]. Norberg-Hodge, Helena (2006) Globalization and Terror in Adedimeji, Mahfouz (2006) Globalization and the Survival of the Nigerian Cultural and Linguistic Heritage: The American Paradigm. Department of English, University of Ilorin, Nigeria.

[24]. Nwaegbu, Mercy U, Eze, Cyril U, and Asogwa, Brendan E (2011) Globalization of Cultural Heritage: Issues, Impacts, and Inevitable Challenges for Nigeria. Available at http://unnllib.unl.edu/lpp.

[25]. Nwana,O C (1981) Introduction to Educational Research for Student and Teachers, Ibadan: Hienman Educational Books Ltd

[26]. Odimegwu, Christy (2007) Communalism and Contemporary African Education: Enhancing Integration in Nwaegbu, Mercy U, Eze, Cyril U, and Asogwa, Brendan E (2011) Globalization of Cultural Heritage: Issues, Impacts, and Inevitable Challenges for Nigeria. Available at http://unnllib.unl.edu/lpp.

[27]. Ogunjimi, Bayo and Abdul-rasheed Na'Allah (2005) Introduction to African Oral Literature and Performance. Trenton, NJ: Africa World Press, Inc.

[28]. Oni, Adesoji A (2005) Globalization and Its Implication on African Culture and Development: Challenges for Education. International Journal of African and African American Studies 4(2)

[29]. Onyeonoru Ifeanyi (2003) "Globalization and Industrial Performance in Nigeria"

[30]. Africa Development Vol. Xxviii. Nos. 3.

[31]. Sawyer, A. (1998) "Globalisation and Social Sciences in Africa" Presidential

[32]. Address at the 9th General Assembly of Codesria Dakar December.

[33]. Scholte, J A., (2002) "What is Globalization? The Definitional Issue - Again"

[34]. Center for the Study of Globalization and Regionalization (CSGR). Working Paper No 109/02, University of Warwick.

[35]. Semiu Musa Bello and Adesemoye (2012) "Western Films and Teenagers in Nigerian Societies: The Question of Cultural Promotion." Continental Journal of Arts and Humanities 4(2).

[36]. Sotshangane Nkosinathi (2002) "What Impact Globalization has on Cultural Diversity" Alternatives:Turkish journal of international relations. I(4)

[37]. Taylor, Charles (1994) The Politics of Recognition in Sotshangane Nkosinathi (2002) "What Impact Globalization has on Cultural Diversity" Alternatives:Turkish journal of international relations. I(4)

[38]. Wilfred Felix (1997), Globalization and Cultures: The Other Voice. Bulletin of ecumenical theology, 9(12). 